\title{
INTELLECTUAL PROPERTY AND CORRECTIVE JUSTICE
}

\author{
Jules L. Coleman*
}

$\mathrm{T}$

HESE remarks are stimulated by Professor Wendy Gordon's ambitious and extremely interesting article On Owning Information: Intellectual Property and the Restitutionary Impulse. ${ }^{1}$ Professor Gordon identifies some current trends in the law of what she variously refers to as "intangible" or "intellectual" property. ${ }^{2}$ In doing so, she emphasizes the expansion of legal protection afforded certain property claims in intellectual resources ${ }^{3}$ and considers possible motivations for the change in legal attitude, notably the increasing economic importance of intangibles. ${ }^{4}$ Professor Gordon rightly notes that more protective common law causes of action may be economically counterproductive. ${ }^{5}$ In her view, legal protection of intangibles has increased in two important ways. The first concerns the domain of protected interests; the second concerns the nature of the protection given the relevant interests. ${ }^{6}$ Professor Gordon identifies two principles underlying the expansion of both the domam and the nature of intellectual property law. These are: (1) the principle of reap/sow, ${ }^{7}$ and (2) the principle of unjust enrichment. ${ }^{8}$

The reap/sow principle itself contams two components. On the one hand, the principle posits that those who have not sown have no right to reap; on the other hand, it claims that those who have sown have a right, therefore, to reap. ${ }^{9}$ These claims are vastly different. One could advance the view that those who have contributed to the value

\footnotetext{
* John A. Garver Professor of Jurisprudence and Philosophy, Yale University and Yale Law School.

1 Wendy J. Gordon, On Owning Information: Intellectual Property and the Restitutionary Impulse, 78 Va. L. Rev. 149 (1992).

2 Id. at $150-52$ \& nn. 3-12.

3 Id. at 152-55.

4 Id. at $157 \&$ n. 25.

5 Id. at 157-61.

6 Id. at $156-57$.

7 Id. at 166-96.

8 Id. at 196-221.

9 Id. at $169-70$.
} 
of something thereby are entitled to share in the resulting benefits without excluding from the receipt of benefits others who have not contributed to a resource's mcreased value. On this understandmg of the reap/sow principle, it does not follow that imdividuals who have benefited from another's labor are precluded from benefiting (or that their benefiting is wrongful), or, alternatively, that they owe compensation for receiving such benefits. Any strong conclusion about the duties of so-called free riders to those upon whose backs they ride will require both components of the reap/sow principle and may require considerably more.

The principle of unjust enrichment posits that wrongly or unjustly secured gains must be aunulled. Put this way, the principle offers little guidance to a common law judge. Among other things, it fails to specify to whom the wrongly secured gains should be given. Standing alone, unjust enrichment does not require that gains be given to the mdividual whose labor created them. I may act unjustly in taking from you that to which $I$ have no right, but unless you have a right to it, it does not follow that the ill-gotten gains I disgorge should become yours. We must account for the grounds of your claim to compensation, as well as my duty to forgo my ill-gotten gains. The principle of unjust enrichment may explam the latter but not the former.

A further, unavoidable problem is that any such principle, whether reap/sow or unjust enrichment, will not be self-explanatory or otherwise uncontroversial. The formulation of the principle will control the demands it imposes, and the formulation is ultimately a matter of contestable, normative argument. Deciding what counts as reaping, in addition to what counts as sowing, requires nornative interpretation. Does sowing necessarily mvolve adding value? Must there be effort? Should the extent to which one reaps reflect the degree of effort involved or the marginal contribution (that is, the value added)? Are all the profits associated with sowing legitimately the right of the agent, even so-called economic rents above opportunity costs? The concept of an unjust enrichinent is equally problematic. Is any nonconsensual taking of another's entitlement an unjust enrichment, or must it be a wrongful or unjustified taking in order for the gam to be wrongful? More fundamentally, is the absence of consent the proper criterion of wrongfulness? 
Professor Gordon explores the principle of unjust enrichment largely withm the context of her account of corrective justice. ${ }^{10}$ She rightly notes that the principle of unjust enrichment is connected closely to the principle of corrective justice, citing my claim that corrective justice requires the annulment of wrongful gains and losses. ${ }^{11}$ Unjust enrichments are wrongful gains, so the claim of corrective justice encoinpasses the principle of unjust enrichment. On the other hand, although the reap/sow principle is compatible with some conceptions of corrective justice, it is not obviously required by any of them. For example, one's entitlements may derive from a criterion of need or equality. If so, corrective justice may require rectification of unjustifiable departures from the set of egalitarian rights, not those based on reap/sow notions. Making sense of the claims of corrective justice, therefore, does not require the invocation of reap/sow.

Reap/sow governs entitlements or holdings, whereas the principle of unjust enrichment governs departures from a set of holdings or entitlements. Thus, the reap/sow principle and the principle of unjust enrichment, or corrective justice, are on different levels of analysis. Strictly speaking, they cannot be answers to the saine question. If they are both possible explanations of the explosion in the protection of intellectual property interests, they must explain different aspects of the problem: (1) how do we fix entitlements in intangibles, and (2) what justifies requiring recompense for the use of those entitlements without the consent of the entitled party? These are small points of contention, and I offer thein largely to help Professor Gordon further clarify the nature of her enterprise.

One of the interesting features of Professor Gordon's article is the extent and depth of her attempt to locate the foundation of our current practice in moral, not economic, theory. This approach sets her apart froin most current legal theorists in the intellectual property field. Another attractive feature of her work is the extent to which she attempts to develop and apply aspects of $m y$ theory of corrective justice. Not everyone, however, will view this as a virtue.

Professor Gordon rejects one interpretation of corrective justice ${ }^{12}$ before proceeding to develop a more sophisticated account of correc-

\footnotetext{
10 Id. at 171-77.

11 Id. at 164 n. 54 .

12 Id. at 172-77.
} 
tive justice's place in the explanation and justification of intellectual property law. ${ }^{13}$ Before considering that account, however, I want to consider her rejection of the interpretation that she calls "status quo corrective justice," because I do not think she has put the thesis quite correctly nor given its best defense. Indeed, I advocate a version of what she rejects as the unsophisticated view. I believe that the unsophisticated view can be made either more sophisticated or more attractive in other ways.

In what Professor Gordon terms the primitive interpretation of corrective justice, she identifies corrective justice with the conservative principle that requires rectification of unjustified departures from the status quo. ${ }^{14}$ She notes many flaws in this account. The first is that the status quo itself inay be quite unjust, so that justice seemingly cannot require its reestabhishment. ${ }^{15}$ In other words, if the status quo is unjust, then individuals inay not be entitled to that which they have at any given time. But, if individuals are not entitled to what they have at any given time, how can it be that they are entitled to protection of those holdings? A restoration of unjust holdings cannot be based on a principle of corrective justice, as a way of stabilizing expectations, even if it could be based on economic grounds.

Furthermore, Professor Gordon notes, not every departure froin an existing distribution of holdings creates a wrongful gain or loss. ${ }^{16}$ Gifts and contracts are permissible redistributions of holdings. ${ }^{17}$ Moreover, justifiable harıns or injuries also inay give rise to permissible losses and redistributions, as is often the case in coinpetitive businesses. Thus, even causing harm inay be insufficient to create a duty of repair for loss, and the principle of "status quo corrective justice" cannot be the right place to locate a justification or an explanation of the current practice in the area of intellectual property. ${ }^{18}$

Can the nnsophisticated view be rehabilitated? Professor Gordon's central criticism implicates the relationship between corrective and distributive justice. To return to her categories of "reap/sow" and "unjust enrichment," we might say that the forıner specifies a crite-

13 Id. at $180-96$.

14 Id. at 174.

15 Id. at 173-74.

16 Id. at 174.

17 Id. at 173.

18 Id. at 174-77. 
rion or standard of distributive justice, whereas the latter represents aspects of a theory of corrective justice. Essential to Professor Gordon's rejection of the primitive form of corrective justice is the claim that justice caimot require the restoration of unjust existing distributions. My resolution of this tension is that corrective justice is independent of distributive justice in the sense that the validity of a claim in corrective justice is not determined by the justice of the underlying distribution.

How, then, can corrective justice be a matter of justice? The answer is that corrective justice is an aspect of what I call "transactional justice." Any commumity will have norms governing the transfer or the movement of resources from one person to an other. There will be, therefore, ways of moving resources compatible with those norms, and there will be other ways that violate them. Corrective justice claims arise when the transfer of resources violates the relevant transactional norms. This is transactional mjustice, not distributional or structural injustice. Corrective justice eliminates distortions that arise from unjust or wrongful transfers, which are violations of transactional norms. The net effect of rectifying these wrongs may be restoration of a preexisting distribution. Nevertheless, the purpose of rectification is not to restore the preexisting state of affairs. The justification derives from annulling the distortion, not from recreating the status quo ante. The point of corrective justice is to nullify unjust or wrongful departures from a preexisting state of affairs, for we recognize a distinction between legitimate and illegitimate ways of redistribution, even for unjust patterns of holdings. That is the heart of corrective justice as I understand it.

Pursuing this line of argument, we might ask what some of these norms of transactional justice might be. Consider two broad possibilities. First, no one should be allowed to take from another without sufficient justification. Suppose you possess a resource. Morally, you may not be entitled to it or otherwise have a right in it. It does not follow that I am free to use it as I see fit, whatever my reasons for doing so. At a minimum, I should have good reasons for taking from you what is not mine-even if it is not, morally speaking, yours. If I take without sufficient justification-in torts we might call this "fault"- then I have taken wrongfully, and unjustly enriched myself, regardless of whether you had a right to the resource in question. 
This is one way in which I can secure a wrongful gain without your suffering a wrongful loss. ${ }^{19}$

Another possible transactional norm could hold that if an individual both possesses and has a legitimate right to a certain resource, then one cannot use that resource without first securing the consent of the entitled person. That the individual is said to have a moral right to the resource in question changes the normative relationship between the parties, and the transactional rules as well. If it is justifiably yours, then you are entitled to control the terins of its transfer. In that case, I wrong you every time I take without your consent--even though there may be occasions, such as necessity cases, in which $I$ ain justified in doing so. Unlike cases of the sort just considered, my having a justification does not defeat your claim to repair. In such cases, you inay suffer a wrongful loss though I have secured no wrongful gain. The wrong is iny violation of the transactional norm that requires ine to respect the autonomy that your entitlement confers upon you.

It is easy to see why Professor Gordon conjoins reap/sow and unjust enrichment. Reap/sow provides a potential justification for a system of property entitlements grounded in individual autonomy or in control over the use of a resource. Unjust enrichment compensates those who take without securing the consent of entitlement holders. The problem is that there is no reason to require reap/sow as the underlying theory of justified holdings, and unjust enrichment covers gains that arise at the expense of others even in the absence of a justified underlying entitlement. ${ }^{20}$

Although Professor Gordon dismisses too quickly the simple corrective justice principle, she does not dismiss corrective justice altogether. She proposes that, at a minimum, we all are entitled to

19 As an aside, I have always viewed the structure of this argument as independent of any particular theory of what constitutes a good reason or an adequate justification for taking what another possesses. Considerations of economic efficiency, for example, inay provide a theory of justification or wrongfulness within the structure of this theory of corrective justice. In that event, as I hope this argument makes clear, corrective justice is not reduced to economic efficiency but becomes compatible with it.

20 Again, as an aside, this is part of the reason why I always separate the question of whether a gam or loss ought to be annulled from the question of who should be hable to whom. If $I$ have no underlying entitlement, then even if you wrongly gain by using a resource I possess, it does not follow that I should be entitled to recover-even if it does follow that your gain should be disgorged. 
control our own labor. ${ }^{21}$ This might mean at least two things: first, that we can labor for our advantage at our discretion; and second, that we cannot be compelled to labor at another's will. So if we have any property rights at all $\mathrm{m}$ the sense $\mathrm{I}$ just explained, we have them in our labor. Even this entitlement is limited, however. We cannot labor for our advantage if there is no demand for our labor. On the other hand, it may be that no one can compel our labor. Assummg the validity of the latter proposition, let us see where it takes us.

If you create an idea or some other intangible and I then inake use of it, Professor Gordon claims that if I do not pay you I have compelled your labor in some sense that violates your right to control your own labor. Thus, considerations of corrective justice require that I compensate you. ${ }^{22}$ Compensation is a matter of justice because it rectifies gains and losses that result from my domg to you what I had no right to do, namely, coinpelling your labor.

Accepting the soundness of this argument for the moment, we can move on to consider Professor Gordon's use of it. She asserts that not every case in which I make use of, or benefit from, your labor constitutes my compelling your labor. ${ }^{23}$ Thus, she beheves that we need an account of the constraints that should be imposed upon someone who benefits at another's expense before we can conclude that compensation is owed to the laborer. ${ }^{24}$ What constraints are plausible? At this point, Professor Gordon introduces the core of her thesis. She rightly notes that we need a model for thinking about the problein. She offers the law of restitution. ${ }^{25}$ Why restitution? Why not torts? A person who uses an idea or other invention benefits at the laborer's expense. The law of restitution presumably rectifies that benefit if it is an unwarranted or unjustified one. In contrast, the law of torts rectifies the wrongful losses that the injurer has imposed upon the plaintiffvictim. Professor Gordon claims that torts articulates a jurisprudence of harms and that restitution, in contrast, articulates a jurisprudence of benefits. ${ }^{26}$ Thus, if we are to look for the appropriate constraints on a laborer's claim to coinpensation for the use to which others put

21 Gordon, supra note 1 , at 181 .

22 Id.

23 Id. at 182-96.

24 Id. at 196.

25 Id. at 196-221.

26 Id. at 159. 
her property, she views the law of restitution, and the jurisprudence of benefits it represents, as the place to look.

I have doubts about the motivation Professor Gordon presents for employing the restitutionary model. She begins with the corrective justice claim that recompense for loss requires the impairment of an underlying entitlement to provide a claim to repair. The relevant entitlement is the right not to labor other than at one's own discretion. ${ }^{27}$ If, however, the basis of intellectual property law is this entitlement not to labor other than at one's discretion, then the principle of reap/sow appears to have hittle to do with the foundations of the law, because the claim is not that one is entitled to what one sows. Rather, the claim is that others are not entitled to compel one to sow-no matter who stands to benefit from one's doing so. Moreover, the basis of the alleged right not to labor other than at one's discretion is not obvious, nor is the idea that we even have such a right.

Additionally, for Professor Gordon, who wants to demystify intellectual property law by ridding it of any natural-law roots it might have, it is especially important that the so-called right not to labor for another can be given a nonnatural-law foundation. Does the entitlement follow from a more general right to do what one wants, a natural right to be free? In my view, we cannot even think about whether we have such a right apart from how we think about pohitical rights more generally. If we view pohtical associations as schemes of rational cooperation for mutual advantage-not an altogether implausible view and one that $I$ have endorsed from time to time-then the teruns and norins of rational cooperation will determine whether one has a right not to labor other than at one's discretion. The terins of rational cooperation may well demand that one's labor be compelled in Professor Gordon's sense of the terin. For example, a rationalchoice political theory may demand that economic rents above opportumity costs be confiscated. That is, after a certain point, the benefits of one's labor are secured by others. If securing benefits requires compelling labor, then in such a political association imdividuals would not have the right to be free froin this sort of compelled labor. Simply put, I cannot decide in the abstract whether there is a right of the sort Professor Gordon posits. The problem of pohitical association must be better or more tightly structured or framed. If the right not to

27 Id. at 181. 
have one's labor compelled is to be grounded as a political rather than a natural right, we need a model of the political right.

Suppose I make use of some discovery or idea of yours and reap the benefits of doing so. It hardly follows that I have compelled your labor. I have benefited from your labor and I may have cheated or wronged you, but there is no obvious sense in which I have compelled your labor.

Moreover, who cares? I need not have compelled your labor for you to have a claim against me. I need to have harmed or wronged you, and there are any number of ways of my doing that without compelling your labor. Professor Gordon is misled by her belief that the rectificatory model requires an underlying entitlement. I can wrong you by unjustifiably interfering with or setting back a legitimate interest of yours, an interest that need not rise to the level of a right. On the other hand, if I do compensate you for the benefit I secure, that does not mean I have not compelled your labor. I may both compel and transfer, as im forced transfers in torts. Compulsion describes the moral character of my conduct ex ante; compensation may contribute to its moral character ex post.

Next, Professor Gordon contends that restitution law provides the right model largely because the claim to compensation is based upon the benefit the defendant secures. Restitution is the jurisprudence of benefits; torts the jurisprudence of harms. I am not persuaded by this argument. First, if the benefit of the defendant is the source of the action, what role does the plamtiff's right not to have her labor compelled play in the argument? One answer is that the plaintiff's entitlement not to have lier labor compelled provides the basis of the claim that the defendant's benefit was wrongful or unjust; it violated or infringed the plaintiff's right. In this view, the plaintiff's right is important because it enables us to determine which of the defendant's gains are unjust. This is unconvincing because there are many ways of acting contrary to constraints imposed upon one by the rights of others that nevertheless are not wrongful. Necessity cases may be of this sort. Vincent v. Lake Erie Transportation $\mathrm{Co}^{28}$ is the paradigm. If $I$ take from you to save the lives of many, I nonetheless inay infringe your rights. It hardly follows, however, that the gains made possible by the infringement are unjust or wrongful and need to be

28124 N.W. 221 (Minn. 1910). 
disgorged. Notwithstanding the absence of wrongful gain, your losses inay be wrongful because they result from the invasion of your rights, and you may have a right to their repair as a result. But here we are talking about benefits, and it is not obvious that conduct that invades another's right-any right-inakes benefits wrongful or unjust, although it may make losses wrongful or unjust in a narrow sense.

If the entitlement is relevant to the cause of action, then perhaps coinpensation is for the wrong done and for the loss that wrong creates rather than for the benefit secured. Is it the harm done or the benefit secured that is the basis of the claim to repair? If the former, tort inay be the appropriate model; if the latter, restitution inay be. The relevance of the entitleinent suggests the tort model, and nothing Professor Gordon says, including her hypothetical bargaining approach, convinces me of the appropriateness of the restitution model. After all, as economists have reminded us time and again, tort law also can be modeled in hypothetical contract terms.

In conclusion, while Professor Gordon's article is thoughtful, original, and exciting, both theoretically and practically, it fails to explain satisfactorily the restitutionary impulse. Professor Gordon ultimately may be correct that the best account of intellectual property law is to be found in restitutionary practices, but the argument she presents is inadequate to that task. I hope, however, that these comments encourage rather than discourage her efforts to locate such an argument. 